\title{
Efficient Utilization of Waste Carbon Source for Advanced Nitrogen Removal of Landfill Leachate
}

\author{
Kai Wang, Wenjun Yin, Fengxun Tan, and Daoji Wu \\ School of Municipal and Environmental Engineering, Shandong Jianzhu University, Jinan 250101, China \\ Correspondence should be addressed to Kai Wang; wangkai@sdjzu.edu.cn and Daoji Wu; wdj@sdjzu.edu.cn
}

Received 8 November 2017; Accepted 27 November 2017; Published 24 December 2017

Academic Editor: Shijian Ge

Copyright ( 2017 Kai Wang et al. This is an open access article distributed under the Creative Commons Attribution License, which permits unrestricted use, distribution, and reproduction in any medium, provided the original work is properly cited.

\begin{abstract}
A modified single sequencing batch reactor (SBR) was developed to remove the nitrogen of the real landfill leachate in this study. To take the full advantage of the SBR, stir phase was added before and after aeration, respectively. The new mechanism in this experiment could improve the removal of nitrogen efficiently by the utilization of carbon source in the raw leachate. This experiment adopts the SBR process to dispose of the real leachate, in which the COD and ammonia nitrogen concentrations were about $3800 \mathrm{mg} / \mathrm{L}$ and $1000 \mathrm{mg} / \mathrm{L}$, respectively. Results showed that the removal rates of COD and total nitrogen were above $85 \%$ and $95 \%$, respectively, and the effluent COD and total nitrogen were less than $500 \mathrm{mg} / \mathrm{L}$ and $40 \mathrm{mg} / \mathrm{L}$ under the condition of not adding any carbon source. Also, the specific nitrogen removal rate was $1.48 \mathrm{mgN} /(\mathrm{h} \cdot \mathrm{gvss})$. In this process, polyhydroxyalkanoate (PHA) as a critical factor for the highly efficient nitrogen removal (>95\%) was approved to be the primary carbon source in the sludge. Because most of the organic matter in raw water was used for denitrification, in the duration of this 160-day experiment, zero discharge of sludge was realized when the effluent suspended solids were $30-50 \mathrm{mg} / \mathrm{L}$.
\end{abstract}

\section{Introduction}

Landfill leachate is produced from municipal waste deposited in the landfill. The leachate contains high concentrations of organics and ammonia nitrogen that are severe pollutants of the subsurface environment [1]. The efficient and costeffective treatment of the leachate, aiming to meet discharge requirements, has become a worldwide interest. There is two kinds of technologies used for leachate treatments: physical/chemical treatment and biological treatment. The physical/chemical methods, such as ammonia stripping or advanced oxidation methods, are usually used for pretreatment or posttreatment because of their secondary pollution and high cost [2-4]. Biological treatments have been widely applied to treat landfill leachate because the reagents are reusable and cost-effective, and these procedures generate less secondary pollution [5-8].

The biological treatment of landfill leachate focuses on the removal of organics and ammonia nitrogen [9-14]. The organics are removed through conventional biological treatments, and the ammonia nitrogen is oxidized into $\mathrm{NO}_{2}^{-}$$\mathrm{N}$ or $\mathrm{NO}_{3}{ }^{-}-\mathrm{N}$ under aeration. Since the $\mathrm{NO}_{2}{ }^{-}-\mathrm{N}$ or $\mathrm{NO}_{3}{ }^{-}-\mathrm{N}$ is more poisonous than ammonia nitrogen, many countries (e.g., China) require that landfills meet total nitrogen (TN) emission standards on the landfill leachate. TN removal via denitrification requires a carbon source. However, most organics in the leachate have been oxidized into $\mathrm{CO}_{2}$ during aeration, resulting in a low concentration of carbon. The conventional biological treatments realize only $30 \%-70 \%$ nitrogen removal efficiency. For example, Laitinen et al. used sequencing batch reactor (SBR) activated sludge process combined with membrane bioreactor (MBR) to dispose of landfill leachate that contained $2200 \mathrm{mg} / \mathrm{L}$ chemical oxygen demand (COD) and $240 \mathrm{mg} / \mathrm{L} \mathrm{TN}$. The TN removal efficiency was below $60 \%$. Yanjie et al. used granule sequencing batch reactors to dispose of landfill leachate, and the removal efficiency of TN was about $35.0 \%$, with the ammonium of the leachate being $1105 \mathrm{mg} / \mathrm{L}$. Mehdi used MBR to dispose of landfill leachate, and the removal efficiency of TN was about $28.0 \%$. Some studies have reported high nitrogen removal in the leachate by adding an external carbon source, but this approach increased the cost and wasted the organics naturally present in the leachate [15]. 
TABLE 1: The characteristics of the leachate.

\begin{tabular}{lcccccc}
\hline Item & $\mathrm{pH}$ & $\begin{array}{c}\mathrm{NH}_{4}{ }^{+}-\mathrm{N} \\
(\mathrm{mg} / \mathrm{L})\end{array}$ & $\begin{array}{c}\mathrm{TN} \\
(\mathrm{mg} / \mathrm{L})\end{array}$ & $\begin{array}{c}\mathrm{NO}_{x}-\mathrm{N} \\
(\mathrm{mg} / \mathrm{L})\end{array}$ & $\begin{array}{c}\mathrm{COD}^{2} \\
(\mathrm{mg} / \mathrm{L})\end{array}$ & $\begin{array}{c}\mathrm{BOD}_{5} \\
(\mathrm{mg} / \mathrm{L})\end{array}$ \\
\hline Range & $7.8 \sim 8.2$ & $860 \sim 1012$ & $910 \sim 1106$ & $0.11 \sim 0.8$ & $3360 \sim 4210$ & $1082 \sim 1380$ \\
Mean value & 8.0 & 1010 & 1021 & $<1$ & 3820 & 1215 \\
\hline
\end{tabular}

\begin{tabular}{|c|c|c|c|c|c|}
\hline Filling & Stir $(0.5 \mathrm{~h})$ & Aeration & Stir & Settle & $\begin{array}{l}\text { Withdraw } \\
\text { and decant }\end{array}$ \\
\hline & & $\checkmark \checkmark$ & & & \\
\hline
\end{tabular}

FIGURE 1: Operational mode of modified SBR.

Compared to other bioprocessing technologies, SBR has many advantages, such as simple structure and flexible operation. SBR has become a widely used method to dispose of landfill leachate [16]. Studies of SBR had focused on the removal of organics and ammonia, but little of them focused on the removal of total nitrogen.

Vock et al. discovered that activated sludge could store a carbon source, by transforming organic carbon from wastewater to the form of PHA stored in bacteria cells [17]. If the carbon-storage capability of the activated sludge could be strengthened, then TN removal would be able to use the stored indigenous carbon source, which would also improve the nitrogen removal efficiency and eliminate the addition of external sources of carbon [18].

To realize high nitrogen removal without the additional external sources of carbon, a modified SBR to treat real landfill leachate was used. The modified SBR differs from conventional SBR by adding a stirring phase before and after aeration phase, which allows for the full use of the carbon source in the leachate. Some parameters of SBR in one cycle which included $\mathrm{COD}, \mathrm{NH}_{4}{ }^{+}-\mathrm{N}, \mathrm{NO}_{2}{ }^{-}-\mathrm{N}, \mathrm{NO}_{3}{ }^{-}-\mathrm{N}, \mathrm{TN}, \mathrm{pH}$, and oxidation-reduction potential (ORP) were investigated. Also, the effect of variation of PHA of the sludge in one cycle of SBR was studied.

\section{Materials and Methods}

2.1. Landfill Leachate and Seed Sludge. Raw landfill leachate for this study was taken from the third MSW Sanitation Landfill Site, Jinan, Shandong province, China. The COD of the leachate was $3360 \mathrm{mg} / \mathrm{L}-4210 \mathrm{mg} / \mathrm{L}$. The ammonia of the leachate was $860 \mathrm{mg} / \mathrm{L}-1012 \mathrm{mg} / \mathrm{L}$, and $\mathrm{NO}_{2}{ }^{-} \mathrm{N}$ and $\mathrm{NO}_{3}{ }^{-}-\mathrm{N}$ could be ignored. The characteristics of leachate were shown in Table 1. Inoculum was obtained from two sources: $80 \%$ of the inoculum is from the excess sludge of a pilot-scale SBR used to treat domestic wastewater, with MLSS and sludge volume index (SVI) being 10,000 mg/L and $350 \mathrm{mg} / \mathrm{L}$, respectively; the rest of the inoculum $(20 \%)$ came from an experimental SBR that had already produced nitridation with mature leachate, with MLSS and SVI being 3,500 $\mathrm{mg} / \mathrm{L}$ and $56 \mathrm{mg} / \mathrm{L}$, respectively. The MLSS, MLVSS, and SVI of the mixture were $8,523 \mathrm{mg} / \mathrm{L}, 6,375 \mathrm{mg} / \mathrm{L}$, and $290 \mathrm{mg} / \mathrm{L}$, respectively.
2.2. Experimental Setup and Operational Procedure. An SBR with working volume of $10 \mathrm{~L}$ was used in this study. The temperature was controlled at $25^{\circ} \mathrm{C} \pm 1^{\circ} \mathrm{C}$ through the temperature control device, and the aeration was controlled through an air pump and gas flow meter.

The operation mode of the modified SBR is shown in Figure 1, including the filling phase, the anaerobic stir phase (synthesis of PHA in activated sludge), the aeration phase (nitration and simultaneous nitrification and denitrification), the anoxic phase (endogenesis denitrification), the settling phase, and the decanting phase, respectively. The dissolved oxygen (DO) concentration of nitritation was maintained in the range of $1.5-2.0 \mathrm{mg} / \mathrm{L}$.

The sludge of the testing which investigated the content variation of PHA in one cycle was taken from the 120th experiment. In the testing, liquid samples and sludge samples were collected every 30 minutes before nitrification and every 60 minutes after nitrification. The liquid samples were analyzed for $\mathrm{NH}_{4}{ }^{+}-\mathrm{N}, \mathrm{NO}_{2}{ }^{-}-\mathrm{N}, \mathrm{NO}_{3}{ }^{-}-\mathrm{N}, \mathrm{TN}$, and COD. The sludge samples were analyzed for $\mathrm{PHA}$.

During the experiment, $\mathrm{COD}, \mathrm{NH}_{4}{ }^{+}-\mathrm{N}, \mathrm{NO}_{2}{ }^{-}-\mathrm{N} \mathrm{NO}_{3}{ }^{-}$$\mathrm{N}$, MLSS, and MLVSS were measured according to standard methods (APHA, 1998). The TN concentration was measured with Multi N/C3000 TOC (Analytik Jena AG, Germany). $\mathrm{BOD}_{5}$ was measured with an OxiTop Control WTW. DO, $\mathrm{pH}$, and ORP were monitored using a $\mathrm{pH} / \mathrm{Oxi} 340 \mathrm{i}$ analyzer (WTW Company, Germany). PHB was determined using the method of Zeng et al. [19].

\section{Results and Discussion}

\subsection{Performance of the Modified SBR}

3.1.1. Quick Launch Strategy of Modified SBR to Realize Leachate Advanced Nitrogen Removal. The start-up phase lasted $35 \mathrm{~d}$ so that the inoculum had time to adapt to the characteristics of the leachate. The volumetric exchange rate (EVR) of SBR during this period was $10 \%$.

In order to enrich the quantity of the denitrifying bacteria, the operation time of anoxic stir stage was 10 hours. If $\mathrm{TN}$ was not removed in one cycle, external carbon sources (such as sodium acetate) were added to ensure the denitration finished. Since the initial SVI was high $(290 \mathrm{mg} / \mathrm{L})$, the 


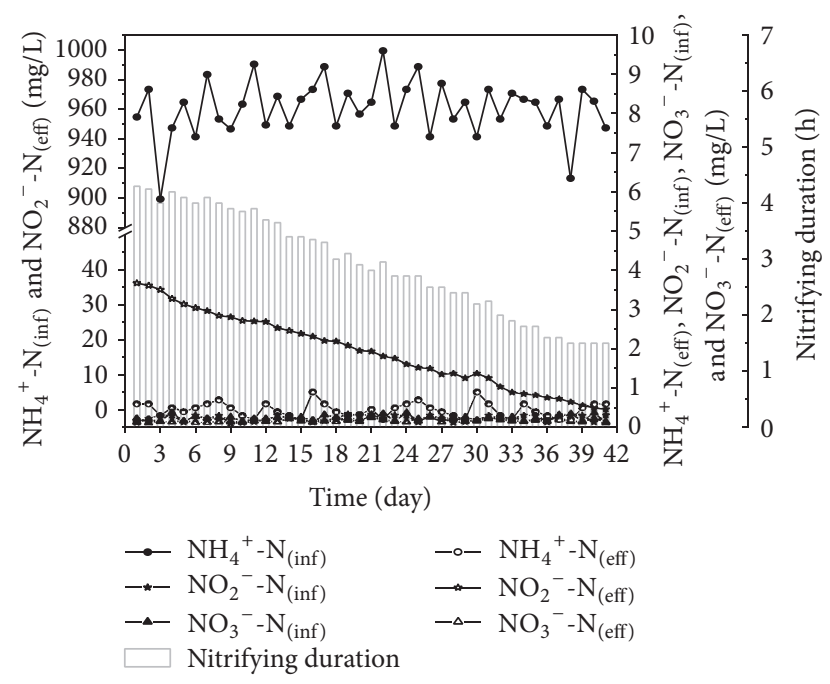

FIGURE 2: Fast start-up performance of modified SBR treating landfill leachate.

settling time was set to $2 \mathrm{~h}$ to ensure the sludge would not flow away. Figure 2 shows the performance of SBR during the start-up phase. The effluent $\mathrm{NO}_{2}{ }^{-}-\mathrm{N}$ concentration was measured at the completion of the anoxic stir stage without the addition of an external carbon source. The activity of the nitrite oxidizing bacteria (NOB) was inhibited because the free ammonia (FA) concentration in the leachate was $1.2918 \mathrm{mg} / \mathrm{L}$ (higher than domestic wastewater $[0.775 \mathrm{mg} / \mathrm{L}]$ ) and the DO concentration was low (i.e., $1.5-2.0 \mathrm{mg} / \mathrm{L}$ ) during nitrification. Therefore, the system successfully achieved nitritation with a low production of $\mathrm{NO}_{3}{ }^{-} \mathrm{N}(\leq 3 \mathrm{mg} / \mathrm{L})$. During the previous $3 \mathrm{~d}$ of the experiment, the sludge did not adapt to the leachate, resulting in a system-specific ammonia oxidation rate (SAOR) of $3.55 \mathrm{mg} \mathrm{NH}_{4}{ }^{+} \mathrm{-N} /$ gvss.h and a nitritation stage that lasted $4 \mathrm{~h}$. Moreover, there was about $35 \mathrm{mg} / \mathrm{L} \mathrm{NO}_{2}{ }^{-} \mathrm{N}$ remaining at the conclusion of the first cycle because of the small amount of denitrifying bacteria. Therefore, an external carbon source was added to remove more of the nitrogen.

After the ammonia oxidizing bacteria (AOB) adapted to the leachate, the nitritation stage decreased from $4.4 \mathrm{~h}$ (1std) to $1.5 \mathrm{~h}$ on 38 th $\mathrm{d}$, while the SAOR increased to $9.64 \mathrm{mg} \mathrm{NH}_{4}{ }^{+}$-N/gvss.h and remained at about $10 \mathrm{mg} \mathrm{NH}_{4}{ }^{+}$ $\mathrm{N} / \mathrm{gvss} \cdot \mathrm{h}$ for the rest of the experiment. The number of denitrifying bacteria grew rapidly in response to the addition of an external carbon source. On 41st d, the system achieved complete denitration without the addition of an external carbon source in one $14 \mathrm{~h}$ cycle, completing the start-up phase of the modified SBR.

3.1.2. Ascension and Stability of Leachate Nitrogen Removal Performance of Modified SBR. After the completion of the start-up phase, the modified SBR system was able to efficiently remove nitrogen without adding external sources of carbon during any part of the cycle. As shown in Figure 3 , the system operated for $30 \mathrm{~d}$ with the $10 \%$ EVR. The cycle completion time decreased from $13.4 \mathrm{~h}$ on $42 \mathrm{nd} d$ to

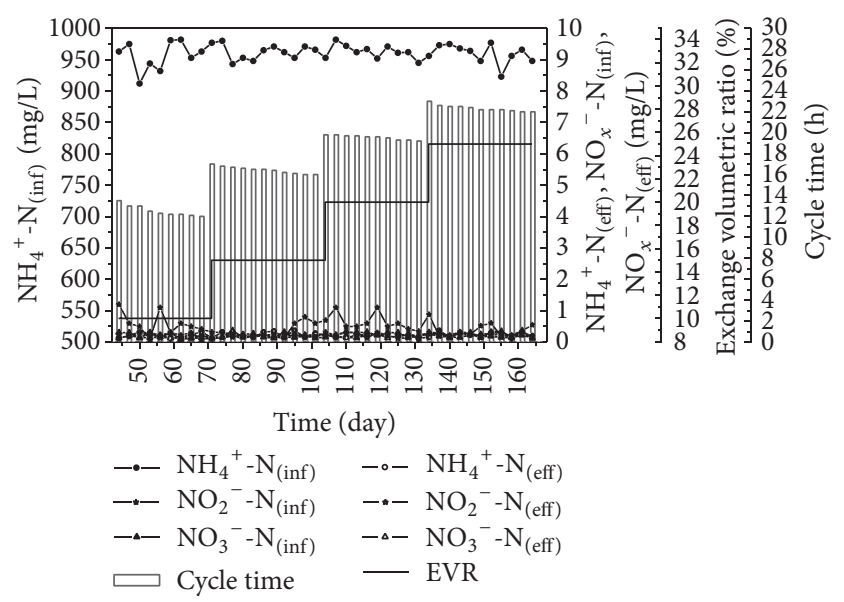

FIGURE 3: Performance of modified SBR treating landfill leachate with nitrogen load increasing.

$12 \mathrm{~h}$ on 70 th $\mathrm{d}$. Accordingly, the specific nitrogen removal rate (SNRR) increased from $0.99 \mathrm{mgN} / \mathrm{h} \cdot$ gvss on $42 \mathrm{nd} \mathrm{d}$ to $1.12 \mathrm{mgN} / \mathrm{h} \cdot$ gvss on 70 th $\mathrm{d}$. After the cycle time was stable, the EVR was increased to enhance the denitrification capability of the sludge. On 71st d the EVR was increased to $15 \%$ and the influent TN of the system increased by $50 \%$. However, the cycle time only increased to $17 \mathrm{~h}$, suggesting an improvement in the denitrification efficiency.

Between 71st $\mathrm{d}$ and 101st $\mathrm{d}$, the cycle time decreased from $17 \mathrm{~h}$ to $16 \mathrm{~h}$ and the SNRR increased to $1.29 \mathrm{mgN} / \mathrm{h} \cdot$ gvss. Then we raised the EVR to $20 \%$ and the cycle time increased to $19.8 \mathrm{~h}$. The cycle time did not improve proportionally with TN (the $20 \%$ EVR was only $65 \%$ longer than the $10 \%$ EVR and $23.7 \%$ longer than the 15\% EVR). On 164th d we increased the EVR to $25 \%$ and the cycle time remained at $22 \mathrm{~h}$ with an SNRR of $1.48 \mathrm{mgN} / \mathrm{h} \cdot$ gvss. The nitrogen removal efficiency of the $25 \%$ EVR increased by $30 \%$, compared to the $10 \%$ EVR.

\subsection{Detecting Reaction Progress with Parameter Variations.} During the SBR reaction process, we could easily discern the conclusion of nitrification and denitrification stages by detecting changes in the system parameters, such as $\mathrm{pH}$ and ORP [20]. Variations of the parameters during one cycle of the modified SBR were shown in Figure 4. When the mixture contained an $\mathrm{NH}_{4}{ }^{+}-\mathrm{N}$ concentration of $225 \mathrm{mg} / \mathrm{L}$ after filling (EVR was 25\%), the nitritation stage lasted $4.5 \mathrm{~h}$. During the 4 th $\mathrm{h}$, a decrease in ammonia (Figure 4 point A) was easily discerned in the $\mathrm{pH}$ profile and signaled the end of nitritation. At this time, the aeration was stopped quickly in order to increase the denitration potentiality of SBR. During the last $3 \mathrm{~h}$ of nitritation, COD levels were greatly reduced, and after $3.5 \mathrm{~h}, \mathrm{COD}$ remained at about $490 \mathrm{mg} / \mathrm{L}$, indicating that the degradable organics had almost been entirely removed. During aeration, the levels of ammonia nitrogen decreased along with $\mathrm{COD}$, which suggests high $\mathrm{AOB}$ activity. $\mathrm{AOB}$ acted as the dominant bacteria because there was no added nitrate. Furthermore, TN was also removed during aeration, as expected simultaneous nitrification and denitrification (SND). By the end of nitritation, TN concentration was 


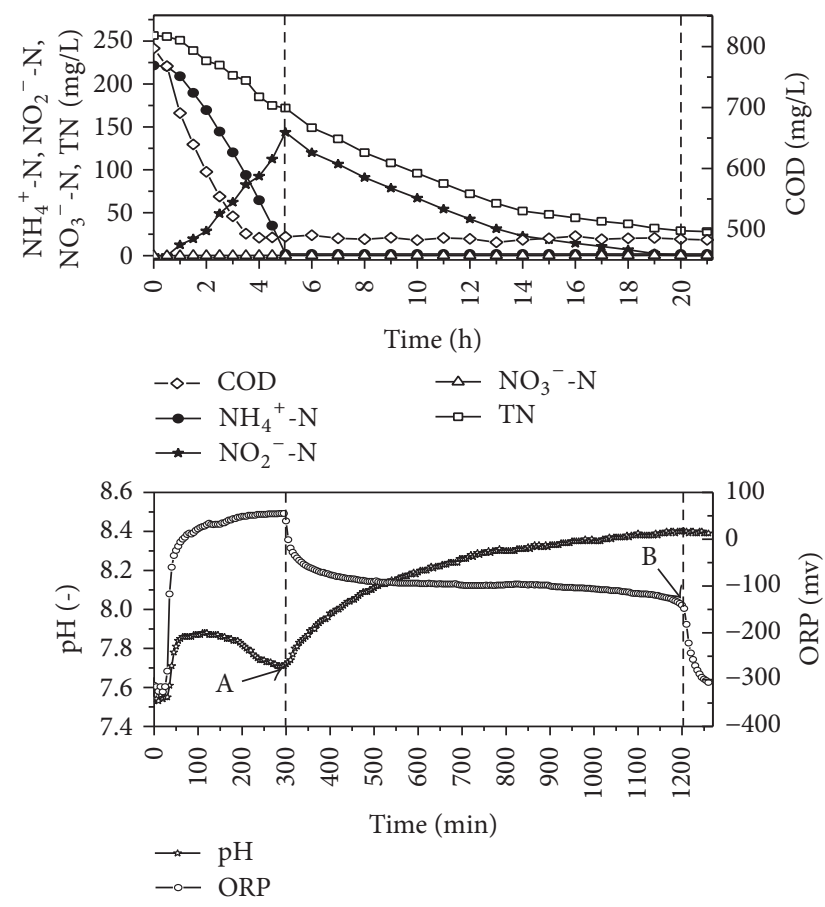

FIGURE 4: Key parameters variations of modified SBR in one cycle.

reduced from $256 \mathrm{mg} / \mathrm{L}$ to $172 \mathrm{mg} / \mathrm{L}$, and the removal rate was $32.8 \%$.

After the nitritation phase, the SBR system began to use the stored carbon source (such as PHA) to denitrify the leachate during a $15 \mathrm{~h}$ anoxic stage. During the 19th and 21st $\mathrm{h}$ of the whole reaction, a nitrate plateau (point B) was recorded in the ORP profile and suggested the end of denitration. At this time, $\mathrm{NH}_{4}{ }^{+}-\mathrm{N}$ and TN concentrations decreased below $5 \mathrm{mg} / \mathrm{L}$ and $30 \mathrm{mg} / \mathrm{L}$, respectively. The nitrogen removal rate was above $95 \%$. It is worth noting that there was no significant change in $\mathrm{pH}$ point during the anoxic stir stage, so the ORP was the only parameter which could be used to judge the terminal point of denitration.

During one cycle, about $2280 \mathrm{mg}$ of nitrogen and $8540 \mathrm{mg}$ of COD were removed. The total amount of COD used during denitration was above $4000 \mathrm{mg}$. At least $46.8 \%$ of the COD was consumed during denitrification. The modified SBR improved the utilization ratio of carbon and also reduced the aeration level in the leachate.

3.3. The PHA Variation of the Sludge in One Cycle. The system realized advanced nitrogen removal without adding any carbon source after aeration. It suggested that the activated sludge used its carbon source for denitrification. To understand the change of carbon sources during the denitrification process, on the 120th d of the test, the variation of PHA, $\mathrm{NH}_{4}{ }^{+}-\mathrm{N}, \mathrm{TN}, \mathrm{NO}_{2}{ }^{-}-\mathrm{N}, \mathrm{NO}_{3}{ }^{-}-\mathrm{N}$, and COD in one cycle was investigated. The test results are shown in Figure 5. According to the results of Figure 5, during the first half hour of the test, as the anaerobic mixing stage, the COD showed noticeable decline, while the PHA of sludge showed visible growth. This suggested that the organic matter of the wastewater was

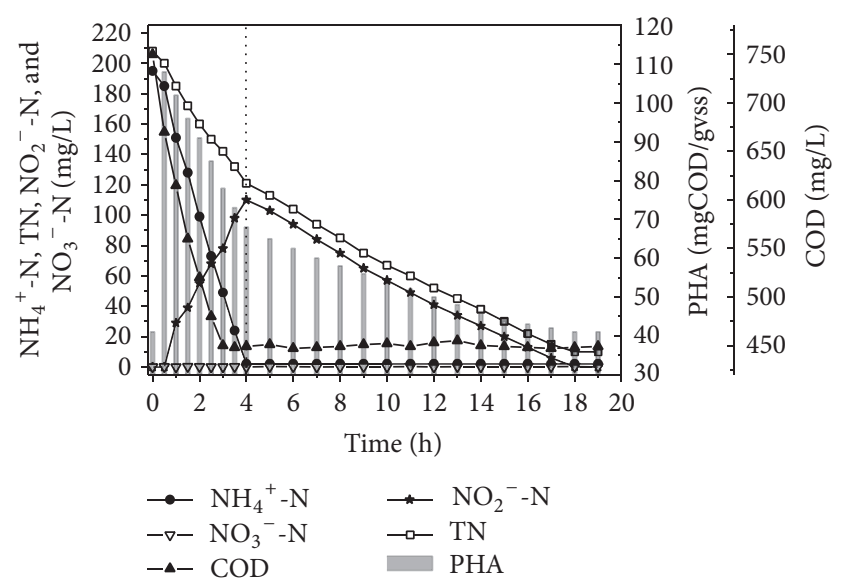

FIgURe 5: PHA variations of modified SBR in one cycle.

adsorbed by activated sludge and then was transformed to PHA. The PHA was the foundation of realizing advanced nitrogen removal. After half an hour, the system started to aerate, and the concentration of ammonia nitrogen and COD decline rapidly. At the same time, the PHA of the sludge was also reduced. Four hours later, the ammonia of the system was less than $5 \mathrm{mg} / \mathrm{L}$ which suggested the end of nitrification. At this point, the COD of the system was about $450 \mathrm{mg} / \mathrm{L}$, and the removal rate of COD was about $85 \%$. Because of the low DO concentration during the aeration, after the nitrification, the total nitrogen removal rate was about $40 \%$ by the simultaneous nitrification and denitrification (SND). The rest of the entire nitrogen mainly exists in the form of the nitrite. After aeration, the concentration of PHA decreased by about $40 \%$ in comparison with the very beginning of aeration, but compared to the beginging of the filling, the concentration of PHA increased significantly.

After the nitration, the system continues to stir. Due to the low dissolved oxygen of the system after stopping the aeration, the sludge began endogenous denitrification. During the process of endogenous denitrification, the concentration of TN and nitrate nitrogen steadily decreased and the PHA decreased synchronously. It is important to note that during the process of denitrification, the level of ammonia was not increased obviously, so we could deduce that the sludge used PHA for denitrification, rather than the carbon source from cell lyses. After 19 hours, the concentration of the nitrate nitrogen was nearly zero, and TN was about $20 \mathrm{mg} / \mathrm{L}$ which showed that advanced nitrogen removal had been completed. At this time, the concentration of PHA in sludge was about $40 \mathrm{mgCOD} / \mathrm{GVSS}$ which is equal to the concentration before filling.

According to this test, we knew that the concentration of PHA in sludge was the key point to realize advanced nitrogen removal. The anaerobic stir after filling provided the sludge opportunity to generate PHA which was the foundation of advanced nitrogen removal. The continue stir after nitration was the approach to realize advanced nitrogen removal. Under the joint action of efficient SND and reinforced 


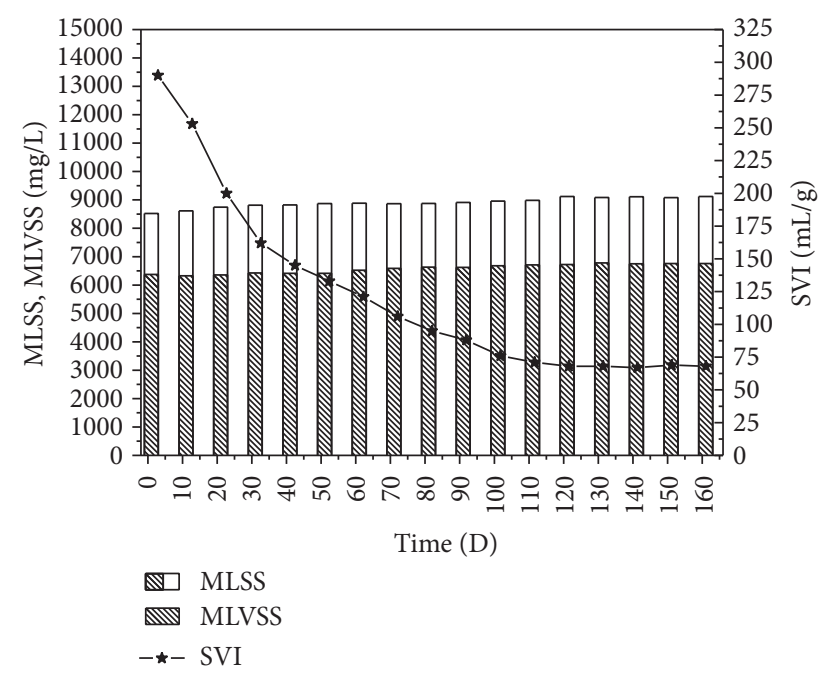

FIGURE 6: Variation of sludge during the experiment.

endogenous denitrification, the system achieved advanced nitrogen removal without any external carbon source.

3.4. Sludge Variation during the Experiment. The activated sludge of modified SBR was fully adapted to the water quality of landfill leachate by more than one hundred days of cultivation and domestication. Variations of the MLSS, MLVSS, and SVI during the experiment were shown in Figure 6. At the beginning, the SVI value was $300 \mathrm{~mL} / \mathrm{g}$. The main reason was that the sludge contained a large number of filamentous bacteria. Since this experiment used alternative anaerobic/anoxic-aerobic modes, the growth of filamentous bacteria was inhibited. After $40 \mathrm{~d}$, the SVI value of the sludge dropped to approximately $150 \mathrm{~mL} / \mathrm{g}$ and then continued to reduce gradually, until eventual stabilization at about $65 \mathrm{ml} / \mathrm{g}$. Since the sludge SVI value was high at the beginning of the test, we adopted tactics to prolong the precipitation time of the activated sludge. Denitrifying bacteria absorbed the vast majority of leachate organic matter, and there was limited growth of aerobic heterotrophic bacteria. In addition, the toxicity of leachate also inhibited the growth of sludge. After more than 160 experiment days, the growth speed of sludge in the system was slow, and there was zero discharge of sludge when the effluent SS was 30-50 mg/L.

\section{Conclusions}

This study modified the SBR operation mode by adding a stirring phase before and after the aeration stage. When the influent mixture had a COD of $3820 \mathrm{mg} / \mathrm{L}$ and a TN of $1000 \mathrm{mg} / \mathrm{L}$, the modified SBR could achieve high COD removal $(>85 \%)$ and extremely high total nitrogen removal $(>95 \%)$ from real leachate without adding any external carbon source, and the maximum specific nitrogen removal rate reached $1.48 \mathrm{mgN} / \mathrm{h}$.gvss.

In this study, the addition of stir before and after aeration was key element to achieve advanced nitrogen removal. The stir before aeration could cause the denitrifying bacterium to absorb carbon source and transfer it into an internal carbon source (e.g., PHA). The stir after nitrification could enable the denitrifying bacterium to realize endogenous denitrification through the utilization of internal carbon. Under the anaerobic/anoxic-aerobic operation mechanism, the utilization rate of organic matter (about 50\%) for denitrification in wastewater was increased significantly. Because of that, during the 160 d experiment, the sludge concentration was maintained in the range of about $8000-9000 \mathrm{mg} / \mathrm{L}$, and the system achieved sludge reduction dramatically.

\section{Conflicts of Interest}

The authors declare that they have no conflicts of interest.

\section{Acknowledgments}

Funding for this project was provided by Shandong Provincial Natural Science Foundation, China (ZR2017BEE067); Science and Technology Planning of Ministry of Housing and Urban-Rural Development, China (UDC2017031712); National Key Research and Development Program of China (2017YFF0209903).

\section{References}

[1] S. Renou, J. G. Givaudan, S. Poulain, F. Dirassouyan, and P. Moulin, "Landfill leachate treatment: review and opportunity," Journal of Hazardous Materials, vol. 150, no. 3, pp. 468-493, 2008.

[2] K. C. Cheung, L. M. Chu, and M. H. Wong, "Ammonia stripping as a pretreatment for landfill leachate," Water, Air, \& Soil Pollution, vol. 94, no. 1-2, pp. 209-221, 1997.

[3] F. Wang, D. W. Smith, and M. G. El.-Din, "Application of advanced oxidation methods for landfill leachate treatment," Journal of Environmental Engineering Science, vol. 2, pp. 413427, 2003.

[4] Y. W. Kang and K. Hwang, "Effects of reaction conditions on the oxidation efficiency in the Fenton process," Water Research, vol. 34, no. 10, pp. 2786-2790, 2000.

[5] F. N. Ahmed and C. Q. Lan, "Treatment of landfill leachate using membrane bioreactors: A review," Desalination, vol. 287, pp. 4154, 2012.

[6] T. Ismail, D. Tarek, S. Mejdi et al., "Cascade bioreactor with submerged biofilm for aerobic treatment of Tunisian landfill leachate," Bioresource Technology, vol.102, no. 17, pp. 7700-7706, 2011.

[7] E. Klimiuk and D. Kulikowska, "Organics removal from landfill leachate and activated sludge production in SBR reactors," Waste Management, vol. 26, no. 10, pp. 1140-1147, 2006.

[8] C.-Y. Lin, F.-Y. Chang, and C.-H. Chang, "Co-digestion of leachate with septage using a UASB reactor," Bioresource Technology, vol. 73, no. 2, pp. 175-178, 2000.

[9] J. Bohdziewicz, E. Neczaj, and A. Kwarciak, "Landfill leachate treatment by means of anaerobic membrane bioreactor," Desalination, vol. 221, no. 1-3, pp. 559-565, 2008.

[10] Y. Peng, S. Zhang, W. Zeng, S. Zheng, T. Mino, and H. Satoh, "Organic removal by denitritation and methanogenesis and nitrogen removal by nitritation from landfill leachate," Water Research, vol. 42, no. 4-5, pp. 883-892, 2008. 
[11] T. H. Hoilijoki, R. H. Kettunen, and J. A. Rintala, "Nitrification of anaerobically pretreated municipal landfill leachate at low temperature," Water Research, vol. 34, no. 5, pp. 1435-1446, 2000.

[12] E. Neczaj, E. Okoniewska, and M. Kacprzak, "Treatment of landfill leachate by sequencing batch reactor," Desalination, vol. 185, no. 1-3, pp. 357-362, 2005.

[13] N. Yusof, M. A. Hassan, L. Y. Phang et al., "Nitrification of ammonium-rich sanitary landfill leachate," Waste Management, vol. 30, no. 1, pp. 100-109, 2010.

[14] C. Visvanathan, M. K. Choudhary, M. T. Montalbo, and V. Jegatheesan, "Landfill leachate treatment using thermophilic membrane bioreactor," Desalination, vol. 204, no. 1-3, pp. 8-16, 2007.

[15] L. Wu, C. Peng, S. Zhang, and Y. Peng, "Nitrogen removal via nitrite from municipal landfill leachate," Journal of Environmental Sciences, vol. 21, no. 11, pp. 1480-1485, 2009.

[16] Y. Wei, M. Ji, R. Li, and F. Qin, "Organic and nitrogen removal from landfill leachate in aerobic granular sludge sequencing batch reactors," Waste Management, vol. 32, no. 3, pp. 448-455, 2012.

[17] M. Vocks, C. Adam, B. Lesjean, R. Gnirss, and M. Kraume, "Enhanced post-denitrification without addition of an external carbon source in membrane bioreactors," Water Research, vol. 39, no. 14, pp. 3360-3368, 2005.

[18] K. Wang, S. Wang, R. Zhu, L. Miao, and Y. Peng, "Advanced nitrogen removal from landfill leachate without addition of external carbon using a novel system coupling ASBR and modified SBR," Bioresource Technology, vol. 134, pp. 212-218, 2013.

[19] R. J. Zeng, R. Lemaire, Z. Yuan, and J. Keller, "Simultaneous nitrification, denitrification, and phosphorus removal in a labscale sequencing batch reactor," Biotechnology and Bioengineering, vol. 84, no. 2, pp. 170-178, 2003.

[20] C. Wu, Z. Chen, X. Liu, and Y. Peng, "Nitrification-denitrification via nitrite in SBR using real-time control strategy when treating domestic wastewater," Biochemical Engineering Journal, vol. 36, no. 2, pp. 87-92, 2007. 

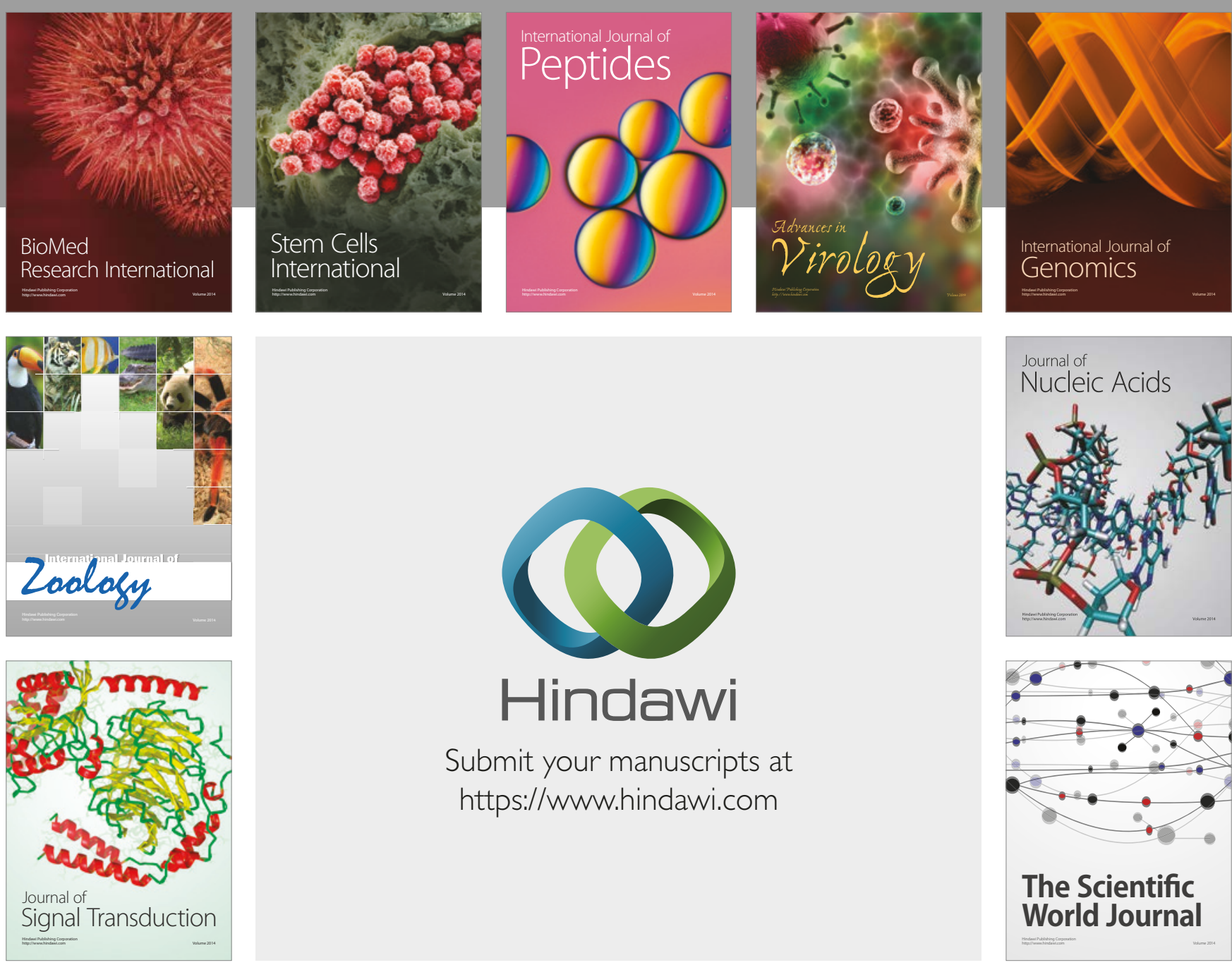

Submit your manuscripts at

https://www.hindawi.com
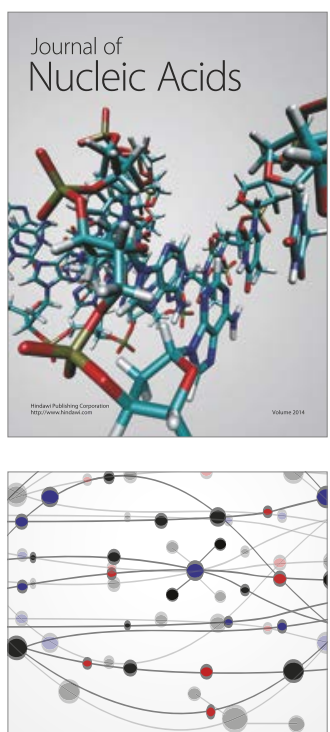

The Scientific World Journal

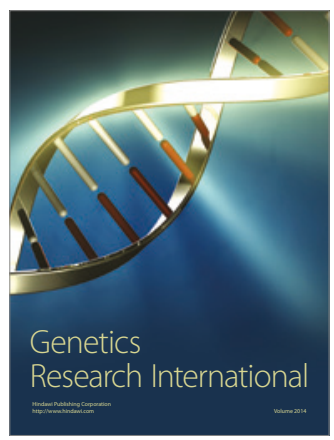

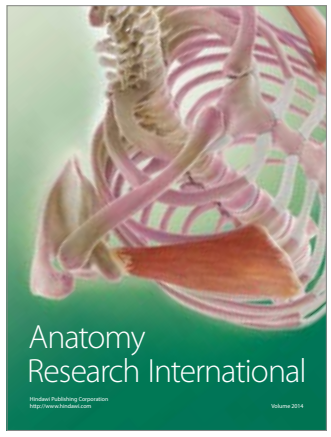

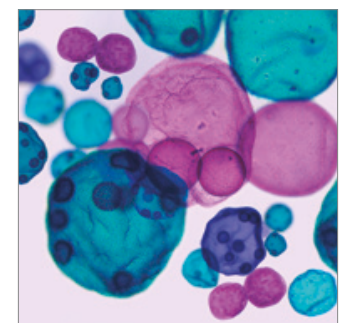

International Journal of Microbiology
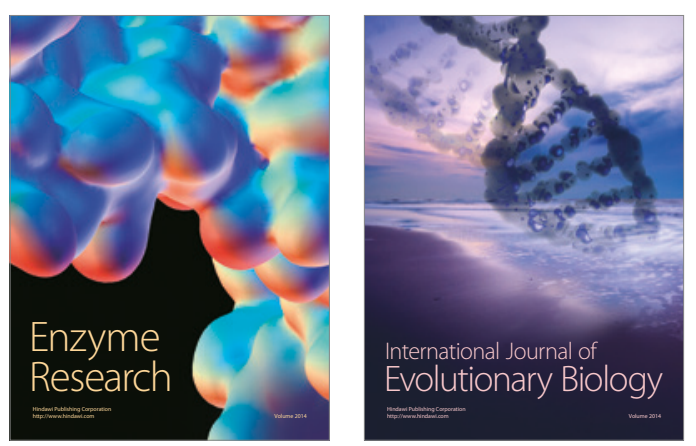
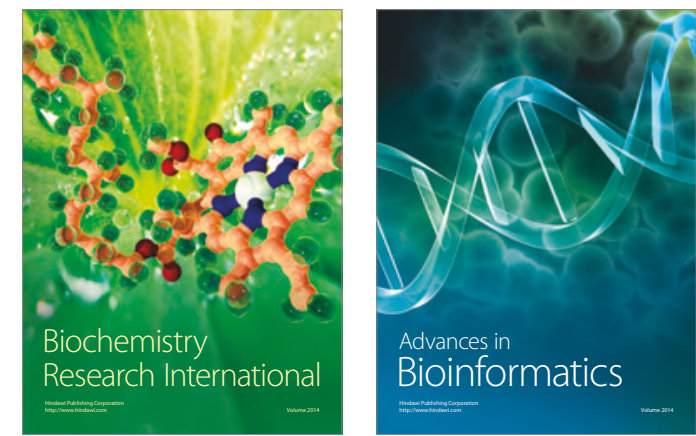

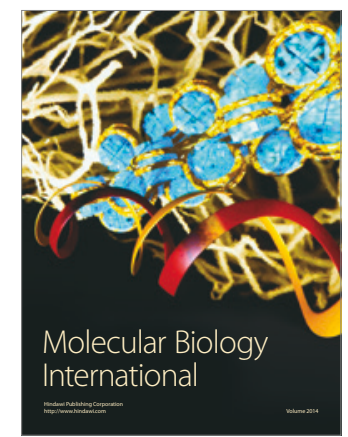

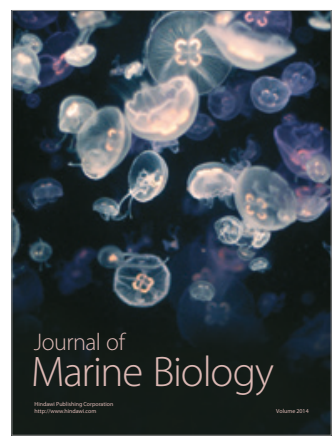

